International Journal of Social Science and Economic Research

ISSN: $2455-8834$

Volume: 05, Issue: 07 "July 2020"

\title{
AN OVERVIEW OF THE NUTRITION CRISIS IN INDIA
}

\author{
Nirvan Bhatia
}

The Shri Ram School, Moulsari

DOI: 10.46609/IJSSER.2020.v05i07.024 URL: https://doi.org/10.46609/IJSSER.2020.v05i07.024

\begin{abstract}
India's Gross Domestic Product has increased by more than $50 \%$ over the past three decades. However, this economic growth has been exclusionary and economically backward communities in the country suffer from the paucity of even those resources that are necessary for sustenance. India is home to more than a third of the world's malnourished children. Deficiencies in nutrition inflict long-term damage to both individuals and society and are considered to be imperative for the emancipation and development of the oppressed sections of society. This paper has explored the structural causes that fuel the nutrition crisis in India. The presence of widespread poverty combined and poor literacy rates amongst women in rural India have been identified as the primary causes. Even though state programs including the National Nutrition Scheme have been adopted, their impact is restricted due to corruption in the state machinery and exclusion of socially oppressed minorities. This paper has also explored the lack of availability and access to infrastructure that facilitates the transportation and storage of food products which leads to high levels of wastage of food produced. It has been found that there is a significant variation in the availability of nutrition in different states in India. Lastly, this paper has sought to provide policy short term and long term recommendations to improve nutrition rates in, centered around poverty alleviation, infrastructural development, women's empowerment and improvements in the implementation of welfare schemes.
\end{abstract}

Keywords: Nutrition crisis, Nutrition, Economic growth, Society, Literacy rates

\section{INTRODUCTION}

India has enjoyed sustained economic development over the past two decades. However, this development has been accompanied by a widening gap between the rich and poor. The economically oppressed sections of the Indian population have largely been excluded from modernization and development, and problems including poverty, unemployment and most 


\section{International Journal of Social Science and Economic Research}

ISSN: $2455-8834$

Volume: 05, Issue: 07 "July 2020"

importantly malnutrition continue to plague these communities. Between 1993 and 2006, the net state domestic product per capita grew by an average annual rate of $4.5 \%$, which signifies a $100 \%$ increase in the real income. However, the living conditions of the economically weaker sections of India have only improved marginally. The prevalence of child stunting and underweight dropped by only $8.7 \%$ and $5.4 \%$ over the 13 years. In China, child stunting fell from $33 \%$ to $10 \%$ between 1992 and 2005 and child underweight was practically eliminated. China is considered to be historically and socially similar to India and the progress of the two countries in development is often compared (Kochar, et. al., 2006). Progress in reducing child malnutrition since the early 1990s has been only marginally better than the progress in Sub-Saharan Africa, a region with high and persistent child malnutrition (Svedberg, 2006). Contrary to India, the economy of Sub-Saharan Africa has been stagnant. The continued prevalence of problems stemming from malnutrition in India shows faulty planning and shortcomings in governance and public policy, which has impacted the development and emancipation of the most oppressed communities in the country.

In the early 1990s, about half of the pre-school children in India were malnourished, as measured by being stunted or underweight for age. At the time, several other countries in South Asia and Sub-Saharan Africa had similar levels of child malnutrition. Stunting is the reduced growth rate in human development, that primarily occurs due to the lack of nutrition (Spears, 2013). The prevalence of child stunting and underweight in India has declined since then, but at a slower pace than in most other developing countries (WHO, 2007). According to data collected in $2008,46 \%$ of all young Indian children were underweight for age and $38 \%$ were stunted (Svedberg, 2008). These figures have barely improved over the past decade. Government records show that In 2017, 59.7\% of children younger than five years of age in India suffered from anemia, 39.3\% were stunted, 32.7\% were underweight, and $21.4 \%$ were born with low birthweight. In absolute terms, $68.2 \%$ of the deaths of children less than five years of age in India in 2017 can be attributed to malnutrition (P.I.B., 2017). India has implemented a range of nutrition programs for the underprivileged that are delivered through schools and communitybased institutions. Through models such as the National Nutrition Mission, the Midday Meal Programme and the National Adolescent Health Strategy combine decades-old program knowledge with modern population-focused approaches. However, data indicates that India will miss its nutrition targets (Bhan, 2019). The potential of many governmental programs has been curbed due to gaps in implementation. Moreover, there is a drastic difference in the performance of different states concerning child nutrition.

India faces acute levels of food shortage every year. India is ranked 102nd out of 117 countries in the Global Hunger Index 2019 (PTI, 2019). The unavailability of food which causes problems ranging from undernourishment to child stunting is less because of low food production and 


\section{International Journal of Social Science and Economic Research}

ISSN: $2455-8834$

Volume: 05, Issue: 07 "July 2020"

more because of the wastage of food which occurs due to the absence of an effective storage and transportation system. Every year in India, about $18 \%$ of fruits and vegetables are wasted due to the lack of post-harvest storage infrastructure. Research conducted by the United Nations' Food and Agriculture Organisation found that, annually, 40\% of India's fresh fruits and vegetables which are worth $\$ 8.3$ billion perish before reaching consumers. This is even though India is the second-largest producer of fruits and vegetables, producing around 83 million tonnes of fruits and 121 million tonnes of vegetables annually (Sivraman, 2016). The lack of development of cold storage and other infrastructural necessities is in part responsible for the prevalence of malnutrition. Malnutrition in India is nothing short of a public crisis and warrants immediate action and policy on the part of the government.

\section{BACKGROUND}

Child malnutrition is measured by the prevalence of stunting and underweight among children and their mothers because they are the most vulnerable groups in India. Most communities in India follow traditional patriarchal norms that are characterized by the subjugation of women and them having lesser say in decision making within households. Moreover, these norms, combined with the absence of public safety for women in India are responsible for the lack of inclusion of women in the workforce. Research suggests that the workforce of India is masculinizing at a rapid rate in the 21 st century (Rukmini 2019). This leads to lower levels of disposable income at the hands of Indian families which hampers their ability to provide for nutritious diets for children. Moreover, the need for education, child healthcare, and nutritious food is often deprioritized in the spending of disposable income, often due to the lack of decision-making avenues available to women in Indian families, especially in rural areas.

Child stunting is defined as a condition in which the height and weight of an individual at a particular age are below two standard deviations from the median height and weight. The agespecific estimates of child stunting and underweight are derived based on the WHO/NCHS norms. Stunting, which is characterized by retarded skeletal growth, is conventionally regarded as the most sensitive marker of long-term deprivation of micronutrients and frequent and prolonged illness (Shrimpton, et. al., 2001). On the other hand, underweight which is associated with a low mass of fat and muscle tissue reflects calorie deficiency and more acute illness (Waterlow, 1992).

There has been a modest decline in child stunting and underweight in India between the years between 1992 and 2006, according to a series of surveys conducted by the National Family \&Health Surveys (NFHS). Over the course of 15 years, child stunting rates in India decreased by $7 \%$ and child underweight rate in India by $4 \%$. India is far from being a homogenous country in 


\section{International Journal of Social Science and Economic Research}

ISSN: $2455-8834$

Volume: 05, Issue: 07 "July 2020"

terms of malnutrition (Svedberg, 2008). Malnutrition is more prevalent in the landlocked northern and central states than in the rest of India. These states are characterized by a high population, high rates of illiteracy and repeated governmental failures in the implementation of welfare schemes. The rates at which the incidence of child stunting and underweight have changed also vary notably across the states. Moreover, in six large Indian states, child underweight increased between the two most recent surveys, which is reflective of a larger systemic problem (Huddinott, 2008). The government of India provides subsidies on a very limited range of food items which can be accessed by the economically weaker sections. However, this system of rationing suffers from two major drawbacks. Firstly, the implementation of this system is marked by instances of corruption and embezzlement of foodgrains. Secondly, socially oppressed classes are denied access to subsidized food due to the perpetuation of practices such as untouchability which are rooted in the ancient caste system of India. The link between social oppression and economic exclusion, which impacts the implementation of many welfare schemes is the reason why the Scheduled Castes and Scheduled Tribe communities are the worst victims of the nutrition crisis.

\section{DISCUSSION}

Research by Svedberg in 2008 suggests that poverty and the lack of female education are associated with malnutrition in states across India. At the level of states in India, the share of the population that can afford a nutritious diet is determined mainly by the average household per capita income, the intra-household distribution of incomes and relative (food) prices - the three main building blocks behind the poverty estimates (Svedberg, 2008). Food comprises about half of the total consumption expenditures of the average Indian household and nearly three-fourths of total consumption expenditure for the lower quartile of the population (according to income level) (Sen \&Himanshu, 2004). Low income hampers households' ability to feed children food with high and balanced micro-nutrient content. Animal products, fruits, and vegetables- food from which key nutrients are derived are invariably more expensive than staple grains. The prices of nutritious foods are not adequately regulated by the government, as price regulation through the storage of food is associated with high levels of wastage.

Women in most parts of India traditionally take up the role of a homemaker in the household. The literacy of mothers is often used to measure maternal ability to care well for children. There are multiple reasons for expecting maternal illiteracy to impair the nutritional status of their children. Firstly, illiterate mothers are at a disadvantaged position to acquire and apply knowledge about appropriate health-care and feeding practices. Despite awareness of lower rates of literacy amongst women in rural India, the government has not released awareness campaigns aimed at promoting the importance of nutrition. The lack of education not only impacts the 


\section{International Journal of Social Science and Economic Research}

ISSN: $2455-8834$

Volume: 05, Issue: 07 "July 2020"

nutrition of children but also that of mothers. Secondly, it has been found that women in India who are illiterate, marry early and have comparatively more children than those who are literate. (Smith, et. al., 2005). This increases the financial pressure on lower-income families and reduces their ability to provide nutritious diets to any of their children. Lastly, it has also been determined that illiterate women are more likely to abstain from exercising their right to vote in local and state-level elections. This severely reduces the propensity of them having an impact on the provision of public utilities including subsidized food and public healthcare. Being chief caretakers of children, mothers in India, just like most countries are tasked with feeding children and seeking health care when they are sick. The possibility of women undertaking these responsibilities, given their abilities, are often constrained by gender-biased cultural values. Most communities of India follow traditional patriarchal norms, which are characterized by the lack of decision making power in the hands of women. Less autonomy of women within their households and in society often leads to a lack of prioritization of children's nutrition and wellbeing in the intra-household allocation of resources (Abadian, 1996). Ancient cultural norms that subjugate women in India and other South Asian countries have been advanced as the main reason why malnutrition in this region is much more prevalent than in poorer Sub-Saharan Africa (Ramalingaswami, et. al., 1996). States where cultural norms are more favorable, such as those in the northeast of India, perform better not only with respect to child nutrition but also with respect to other markers of development.

India is facing an acute agrarian crisis that takes the shape of paradox and harms stakeholders at various levels. High levels of food wastage are accompanied by high rates of malnutrition and the oppression of farmers engaged in food production. This is caused because of the gap that exists between the demand and supply of agricultural produce. The absence of adequate infrastructural and cold-storage facilities leads to the wastage of many indigenously produced food commodities in India that have high nutritional content. There is a dearth of state investment in cold and other forms of storage, and accessing private warehousing or privately investing in storage is impossible for many farmers due to economic constraints. $40 \%$ of India's fresh fruits and vegetable output worth $\$ 8.3$ billion perishes annually before reaching consumers. This also hampers the earning capacity of farmers in India, most of whom are a part of the poorest parts of Indian society and often suffer from compounding debts (Sriram, 2018). Research suggests that programs that are a part of the National Nutrition Mission- tasked with reducing malnutrition in India, including the Midday Meal Scheme, suffer from not only corruption and negligence on the part of state officials but also from structural problems that make them inaccessible to backward castes (Lee \&Thorat, 2005). Untouchability, despite being banned continues to prevail in rural areas of states like Uttar Pradesh and prevents oppressed castes from accessing welfare schemes concerned with the provision of food to the poor. 


\section{International Journal of Social Science and Economic Research}

ISSN: $2455-8834$

Volume: 05, Issue: 07 "July 2020"

Students and women from the Dalit Community have faced active overt discrimination at the hands of public officials and school teachers (PIB, 2012).

\section{CONCLUSION}

The nutrition crisis in India has been a barrier to the development and emancipation of the most vulnerable sections of the Indian population. The lack of availability of food- a necessity upon which is required for basic survival represents one of the biggest shortcomings of subsequent state and central governments in India. Structural and social problems have prevented the implementation of welfare schemes in India. There is a need to include provisions that facilitate long term change as well as those that deal with the immediate crisis in Public Policy. There is consensus, not only among economists, but also among nutritionists, and analysts from the international organizations, that substantial poverty reduction is a necessary and important longterm prerequisite for accomplishing more rapid alleviation of child malnutrition (Svedberg, 2008). The focus should be on increasing labor productivity and income in agriculture, which still ( employs more than half of the Indian labor force. Improving agricultural productivity not only improves the availability of food but also provides additional disposable income to farmers to satisfy their families' nutritional needs. The creation and maintenance of a robust network of storages and transportation of food produced in India are required to not only, moderate retail food inflation and but also maintain the food security of the nation. Empowerment of women by increasing access to formal education and state structures is also expected to improve malnutrition rates. There is a need to inculcate a culture of transparency and accountability within the structures of the state responsible for implementing programs including the Mid-Day Meal Scheme and carrying out functions such as food rationing. Instances of corruption and embezzlement have led to the depletion of state resources and have impacted the quality and quantity of food products. Placing higher accountability on officials and making processes more transparent is imperative to increase efficacy. Special provisions need to be made, which include but are not restricted to the sensitivity training of state officials to enhance the access of historically marginalized social groups to subsidized food and midday meals.

Different states in India are economically, socially and culturally diverse. This is reflective of the variation of human development and nutrition rates across the country. There is a need to conduct targeted research around the nutrition crisis in the worst-performing states, to accurately determine barriers that prevent access to food and formulate contextualized policies. The combination of targeted interventions aimed at alleviating child malnutrition in the shorter term and an overall long-term economic growth strategy that is more inclusive of the oppressed communities is imperative to solve the nutrition crisis in India. 


\section{International Journal of Social Science and Economic Research}

ISSN: $2455-8834$

Volume: 05, Issue: 07 "July 2020"

\section{BIBLIOGRAPHY}

Abadian, S. (1996). Women's autonomy and its impact on fertility. World Development, Accessed on 13th December 2019

Bhan, N. (2019). Solutions to India's nutrition crisis may lie within states. The Lancet, Accessed on 12th December 2019

Huddinott, L. (2008). An overview of malnutrition in India and by state. The Lancet. Accessed on 12th December 2019

Kochar, A. Kumar, U., Rajan, R.(2006). India's pattern of development: What happened? What follows? Journal of Monetary Economics. Accessed on 13th December 2019

Lee, J. \&Thorat, S. (2005). Caste Discrimination and Food Security Programmes. Economic and Political Weekly, Accessed on 10th December 2019

Press Information Bureau. (2012). Caste and Gender Based Discrimination in the Mid Day Meal Scheme. Ministry of Human Resource Development. Accessed on 9th December 2019

Press Information Bureau (2017). Cabinet approves setting up of National Nutrition Mission. Government of India, Accessed on 12th December 2019

Press Trust of India. The Global Hunger Index 2019: India ranked lower than Nepal, Pakistan, and Bangladesh. The Hindu, 17th October 2019

Ramalingaswami, V., Jonson, U., Rohde J. (1996). The Asian enigma. The progress of nations. UNICEF, Accessed on 12th December 2019

Rukmini. S. India's workforce is masculinizing rapidly. Livemint, 10th June 2019

Sen, A. \&Himanshu, G. (2004). Poverty and inequality in India - I and II. Economic and Political Weekly, Accessed on 10th December 2019

Shrimpton, R., Victoria, C.G, de Onis, M., et al (2001). Worldwide timing of growth faltering: Implications for nutritional interventions. Pediatrics, Accessed on 12th December 2019

Smith, L.C. \& Byron, E.M (2005). Is greater decision making power of women associated with reduced gender discrimination in south Asia? FCND Discussion Paper 200: IFPRI, Accessed on 11th December 2019 
Spears, D. (2013). How much international variation in child height can sanitation explain? Policy research working paper. The World Bank, Sustainable Development Network, Water and Sanitation Program, Accessed on 10th December 2019

Sriram, M.S. An Attempt to understand and contextualize farmer suicide rates. Livemint, 28th December 2018

Svedberg, P. (2006). Declining child malnutrition: a re-assessment. International Journal of Epidemiology, Accessed on 6th December 2019

Svedberg, P. (2008). Why malnutrition in shining India persists. Accessed on 8th December 2019

Waterlow, J.C. (1992). Protein energy malnutrition. Edward Arnold, Accessed on 11th December 2019

World Health Organisation (2007). Global database on child growth and malnutrition. Accessed on 9th December 2019 